\title{
Clinton announces package of environmental reforms
}

\begin{abstract}
Washington. US President Bill Clinton used last week's celebration of Earth Day to announce several initiatives that, despite their lack of detail, represent his strongest actions as yet on environmental protection.

As expected, Clinton said he would sign the international biodiversity treaty endorsed
\end{abstract}

IMAGE
UNAVAILABLE
FOR COPYRIGHT
REASONS

Clinton turns green on Earth Day.

last summer by more than 160 nations in Rio de Janeiro (see Nature 362, 577; 1993). And he took the side of Vice President Al Gore against other cabinet members in committing the United States to lowering by 2000 its emission of greenhouse gases to 1990 levels, a provision the Bush administration had kept out of the global climate treaty signed at Rio. How this will happen whether, for example, the US programme will require tough new regulations or rely on incentives - is still to be determined; Clinton has asked for a "cost-effective" plan by August.

Clinton also announced measures to clean up the government's own house, including a commitment that federal agencies will buy ozone-friendly products, energy-conserving computers, fuel-efficient vehicles and recycled products. Clinton ordered agencies with facilities that release toxic pollutants, including military bases and research laboratories, to develop a plan to reduce their output by half by 1999 , and to report them to the public as private companies are now required to do.

In his speech at the National Botanical Gardens in Washington, Clinton made only passing reference to efforts to elevate the Environmental Protection Agency (EPA) to a cabinet-level Department of the Environment, saying that he hoped it would happen "soon, by the grace of Congress". Environmental groups are concerned that the new department will be less capable than the White House Council on Environmental
Quality, which Clinton wants to disband, of enforcing the National Environmental Protection Act and mediating disputes between federal agencies over environmental issues. The Senate may vote this week on a bill to give the proposed department that authority, but the issue is expected to remain controversial when it moves to the House of Representative.

So far the EPA has taken a back seat to the Department of the Interior in shaping new environmental policy in the new administration; Interior Secretary Bruce Babbitt has already taken action on endangered species, land management issues and reorganizing its science programme. In his Earth Day speech, Clinton officially announced the creation of a new national biological survey within the Interior Department (see Nature 361, 574; 1993).

The survey will have an annual budget of $\$ 180$ million, with more than $\$ 100$ million coming from the US Fish and Wildlife Service, and draw on 1,600 employees seconded from within the department. Its duties will include an inventory and monitoring of biological resources as well as providing independent scientific advice on ecological science to officials throughout the government. The scientists reassigned to the survey possess expertise in areas such as population dynamics, physiology, animal behavior, habitats and biodiversity. The reorganization is expected to go into effect on 1 October pending congressional approval of the internal transfer of funds.

In the next few months, the Clinton administration expects to conduct a broad review of federally sponsored environmental science and research. One intent of the review, says Nancy Maynard, an assistant director at the White House Office of Science and Technology Policy, is to eliminate duplication but it is not likely to lead to a wholesale restructuring of agency missions.

A proposal for a National Institute for the Environment to coordinate and fund scientific research on the environment, modelled on the National Institutes of Health, may soon gain the support of the National Academy of Sciences. Although some believe that the institute is unnecessary, an academy panel is expected next month to endorse the basic concept and to propose a possible structure. Representative Jim Saxton (Republican, New Jersey) is preparing legislation to create the institute.

Tony Reichhardt

\section{US-German council formed to strengthen international ties}

Munich. Germany and the United States have formed "an intellectual bridge across the Atlantic" to shore up weakening links between scientists and scholars in the two countries.

The German-American Academic Council was set up this month on the initiative of Germany to support projects and exchanges in science, including social science, and technology. The council will be sponsored by three major research organizations in Germany - the Deutsche Forschungsgemeinschaft (DFG), the Max Planck Society and the Alexander von Humboldt Foundation - and in the United States by the National Academy of Sciences, the American Council of Learned Societies, the American Academy of Arts and Sciences and the Social Sciences Research Council.

So far, Germany is footing the entire bill. The German Ministry for Research and Technology has committed DM18.1 million (US\$11.5 million) over the next four years. US sponsors are being sought among the various private research foundations, but according to Reimar Lüst, president of the Humboldt Foundation, "there is no hurry, the council has enough money to get started".

The idea, conceived by Chancellor Helmut Kohl and endorsed last month in talks between the German leader and US president Bill Clinton, is an attempt to revive the strong transatlantic ties that existed immediately after the Second World War but which have steadily declined as that post-war generation ages. Kohl hopes that the council will become a way to revive these links at a time when Europe is very much looking inwards.

Lüst sees the council as "an intellectual bridge across the Atlantic ... that can be an important vehicle for joint policy studies and interdisciplinary cooperation" in such areas as industrial policy, technical education and the impact of immigration on the national economy. A US-German committee that issued a preparatory report on the need for such a council sees it as a forerunner for an institution to promote cooperation between the United States and all of Europe.

The council will be composed of 30 members, 15 from each country, whose election should be complete within the next few weeks. A main office will be set up in Bonn with a branch office in Washington. The first council meeting is planned for early summer, when the first project grants, for up to 18 months, are expected to be made. Applications from younger scientists will be given priority, as will projects in the humanities.

Alison Abbott 